\title{
STRIGULA MACARONESICA, A NEW SPECIES OF FOLIICOLOUS LICHEN FROM GOMERA AND MADEIRA
}

\author{
Emmanuël SÉRUSIAUX*
}

\begin{abstract}
Strigula macaronesica Sérus., a new foliicolous species found in Madeira and Gomera, is distinguished by its almost linear thallus growing along leaf margins or scars and by its unusually small obclavate asci. (C) 1997 The British Lichen Society
\end{abstract}

\section{Introduction}

Interest in the taxonomy of the genus Strigula Fr. and related genera has recently increased and led to the description of several new species and recombinations (Aptroot \& v. d. Boom 1995; Bricaud \& Roux 1991; Canals et al. 1995; Etayo 1993; Harada 1995; Harris 1995; Lücking 1991; McCarthy 1995; McCarthy \& Malcolm 1996; McCarthy et al. 1996; Roux \& Bricaud 1993; Sérusiaux \& Polly 1996). Indeed, the genus is much more diverse than was previously suspected and several further new species are now known to me. This paper describes one of them, found on living leaves in the macaronesian laurisilva of Gomera in the Canary Islands (Spain) and in Madeira (Portugal).

\section{Strigula macaronesica Sérus. sp. nov.}

Strigula species insignis thallo lineari secus foliorum marginem vel cicatrices crescenti et ascis obclavatis parvisque.

Typus: Portugal, Madeira, Riba do Seixal, S of Seixal, alt. 300-400 m, little disturbed laurisilva, on living leaves of Laurus azoricus, v 1992, Sérusiaux s.n. (LG-holotypus).

\section{(Figs $1 \& 2$ )}

Thallus epiphyllous, subcuticular, typically growing along leaf margins or scars, usually seen as a long linear pale green border, $0.5 \mathrm{~mm}$ broad along such margins or scars with conspicuous black dots (which are perithecia or pycnidia), very rarely half circular and then reaching $1 \cdot 5(-2 \cdot 0) \mathrm{mm}$ diam., bright pale green to cinereous green, smooth and shiny, without any black or white dots, with an undulating margin or with small and rounded lobes, without a prothallus, $40-45 \mu \mathrm{m}$ thick. Photobiont: a species of Cephaleuros (Trentepohliaceae) with more or less rectangular or rounded cells, 8-17 $\times 4$ $6 \mu \mathrm{m}$, yellowish green or green, more or less arranged in radiating rows.

Perithecia usually abundant, but sometimes absent, typically hemispherical with a rounded apex, rarely subconical, single or rarely aggregated in groups ${ }^{\star}$ Research Associate F.N.R.S., Department of Botany, University of Liège, Sart Tilman B 22, B-4000 Liège, Belgium. 


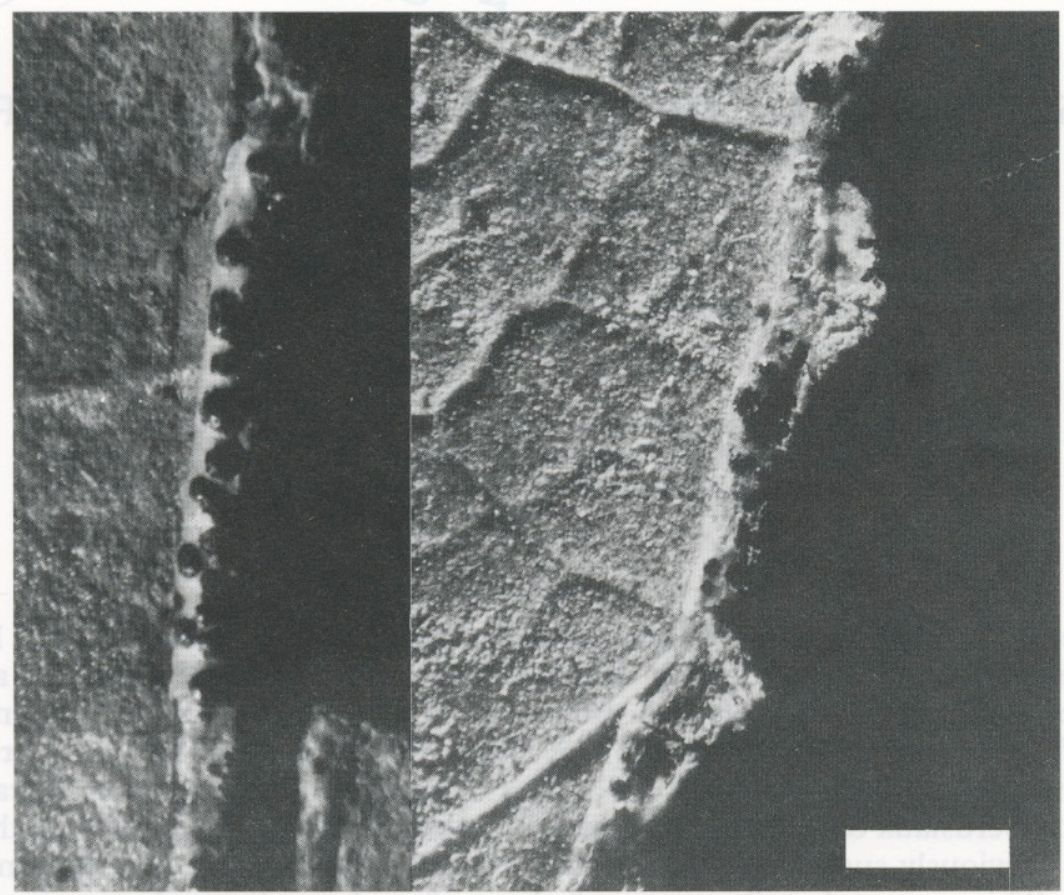

FIG. 1. Strigula macaronesica (holotype): thallus. Scale $=1 \mathrm{~mm}$.

of $2-3(-4)$, black, not or slightly immersed in the thallus, smooth and shiny, $0 \cdot 2-0.25 \mathrm{~mm}$ diam., with a central, almost indistinct ostiole; outer wall and involucrellum black in sections, heavily carbonized, $40-55 \mu \mathrm{m}$ thick near the ostiole; outer wall usually absent under the perithecial cavity; inner wall pale brown, less than $10 \mu \mathrm{m}$ thick, sometimes indistinct; perithecial cavity somewhat flattened, $160-220 \mu \mathrm{m}$ diam., 140-170 $\mu \mathrm{m}$ high; hamathecium of abundant paraphyses that are simple or with a few branches, c. $1 \mu \mathrm{m}$ thick, with several transverse septa; asci bitunicate, with a thickened apex that contains a small ocular chamber, obclavate (best seen in $10 \% \mathrm{KOH}$ ) to shortly cylindrical, $40-44 \times 6-8 \mu \mathrm{m}$; ascospores 8 per ascus, biseriate, fusiform, with rather acute or sometimes rounded ends, 1-septate, usually with 1-2 guttules in each cell and thus appearing 3-septate, especially in $10 \% \mathrm{KOH}$, slightly constricted at the septum, the distal cell slightly larger than the proximal one, without any mucoid appendage, $14-18 \times 4-5 \mu \mathrm{m}$ (measured in Cresyl Blue).

Pycnidia producing macroconidia, black and nitidous, rather flattened, $0.05-0.1 \mathrm{~mm}$ diam., usually present on thalli not producing perithecia; conidiogenous cells lining the bottom of the pycnidial cavity, cylindrical or slightly inflated at their base, or irregular, $10-13 \times 2-3 \mu \mathrm{m}$; macroconidia numerous, subapically produced, bacilliform, with rounded or rather conical ends, 1-septate, 9-10(-11) × 3-3.5 $\mu \mathrm{m}$ (measured in water), slightly but distinctly constricted at the septum, with a mucoid, c. $10-15 \times 1 \mu \mathrm{m}$ 

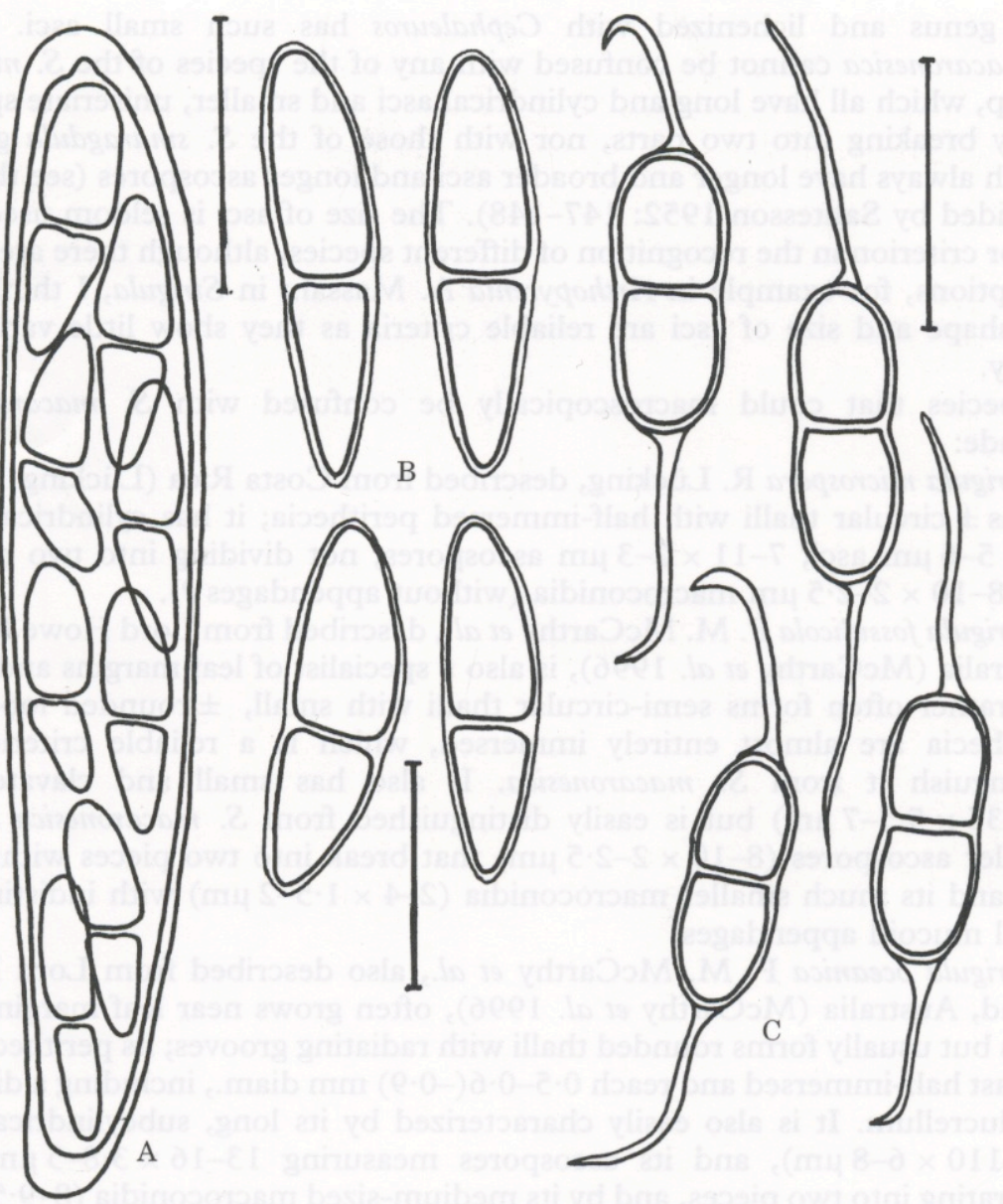

FIG. 2. Strigula macaronesica (holotype): A, Mature ascus with ascospores; B, Ascospores; C: Macroconidia. Scale $=10 \mu \mathrm{m}$.

appendage at both ends that is stretched and usually terminated by a hook. Pycnidia producing microconidia not found.

Notes: This new foliicolous species is easily characterized by its almost linear thallus growing along leaf margins or scars and by its short obclavate asci. Most foliicolous Strigula (incl. Phylloporis Clem. and Raciborskiella Höhn.) manage to reach their niche under the cuticle by initiating thallus growth at the leaf margins or scars; they usually grow typical half-circular thalli. It is remarkable that, in the rather large collections available of $S$. macaronesica, almost all thalli are linear. This feature might be related to the characteristics of the leaves on which they grow but provides a very easy way to identify the species in collections of foliicolous lichens from Macaronesia. The best way to recognize it is nevertheless the size of its asci. Indeed, to my knowledge, no other foliicolous species, except for $S$. fossulicola (see below), belonging to 
this genus and lichenized with Cephaleuros has such small asci. Thus $S$. macaronesica cannot be confused with any of the species of the $S$. nitidula group, which all have long and cylindrical asci and smaller, uniseriate spores, easily breaking into two parts, nor with those of the $S$. smaragdula group, which always have longer and broader asci and longer ascospores (see the key provided by Santesson 1952: 147-148). The size of asci is seldom used as a major criterion in the recognition of different species, although there are a few exceptions, for example in Arthopyrenia A. Massal.; in Strigula, I think that the shape and size of asci are reliable criteria as they show little variation, if any.

Species that could macroscopically be confused with $S$. macaronesica include:

Strigula microspora R. Lücking, described from Costa Rica (Lücking 1991), forms \pm circular thalli with half-immersed perithecia; it has cylindrical, 50 $70 \times 5-6 \mu \mathrm{m}$ asci, $7-11 \times 2-3 \mu \mathrm{m}$ ascospores, not dividing into two pieces, and $8-10 \times 2-2.5 \mu \mathrm{m}$ macroconidia (without appendages ?).

Strigula fossulicola P. M. McCarthy et al., described from Lord Howe Island, Australia (McCarthy et al. 1996), is also a specialist of leaf margins and scars but rather often forms semi-circular thalli with small, \pm rounded lobes; its perithecia are almost entirely immersed, which is a reliable criterion to distinguish it from $S$. macaronesica. It also has small and clavate asci $(28-35 \times 5 \cdot 5-7 \mu \mathrm{m})$ but is easily distinguished from $S$. macaronesica by its smaller ascospores $(8-10 \times 2-2.5 \mu \mathrm{m})$ that break into two pieces within the asci and its much smaller macroconidia $(2-4 \times 1 \cdot 5-2 \mu \mathrm{m})$ with indistinct or small mucoid appendages.

Strigula oceanica P. M. McCarthy et al., also described from Lord Howe Island, Australia (McCarthy et al. 1996), often grows near leaf margins and scars but usually forms rounded thalli with radiating grooves; its perithecia are at least half-immersed and reach $0 \cdot 5-0 \cdot 6(-0 \cdot 9) \mathrm{mm}$ diam., including a distinct involucrellum. It is also easily characterized by its long, subcylindrical asci $(92-110 \times 6-8 \mu \mathrm{m})$, and its ascospores measuring $13-16 \times 3 \cdot 8-5 \mu \mathrm{m}$ and separating into two pieces, and by its medium-sized macroconidia $(8-9.5 \times 2-$ $3 \mu \mathrm{m})$ with long mucoid appendages.

Habitat: Both localities where $S$. macaronesica has been found are rather well or very well preserved stands of laurisilva, the evergreen subtropical cloud forest that is so typical of Macaronesia and represents the Miocene forests of southern Europe that vanished during the glacial times of the Pleistocene period. Thus it may represent a relict species, now confined to the best remnants of that type of forest. In the type locality, other foliicolous species present on the same leaves include Byssoloma leucoblepharum (Nyl.) R. Sant., Fellhanera christiansenii Sérus. \& Vězda, Porina hoehneliana (Jaap) R. Sant. and Strigula nitidula Mont. In Gomera, it is associated with Byssoloma aptrootii Sérus., F. christiansenii, S. smaragdula Fr.: Fr., S. nitidula and Woessia canariensis (Lumbsch \& Vězda) Sérus. The species must be added to the preliminary list of foliicolous lichens occurring in Madeira (Sérusiaux 1996).

Additional specimen examined: Spain, Canary Islands: Gomera, along the track from Chorros de Epina to the Presa de Los Gallos, alt. 700-800 m, laurisilva dominated by Ocotea foetens at the 
bottom of a small valley, on living leaves of O. foetens, 31 vii 1994, Sérusiaux s.n. (B, CANB, E, LG, hb. Lücking, hb. Roux).

I thank the following colleagues and friends for their most valuable comments on the species treated in this paper: Prof. J. Lambinon, Dr P. McCarthy and Dr C. Roux.

\section{REFERENCES}

Aptroot, A. \& v. d. Boom, P. P. G. (1995) Strigula lateralis spec. nov. with notes on the genus fulella (Ascomycetes). Mycotaxon 56: 1-8.

Bricaud, O. \& Roux, C. (1991) Strigula calcarea Bricaud \& Roux sp. nov., espèce nouvelle de lichen. Bulletin de la Société linnéenne de Provence 42: 131-139.

Canals, A., Boqueras, M. \& Gomez-Bolea, A. (1995) Strigula porinoides sp. nov. (Ascomycetes, Lichenes) from the mediterranean karstic regions. Mycotaxon 55: 391-397.

Etayo, J. (1993) Strigula mediterranea, a new name for the forgotten lichen Porina schizospora. Lichenologist 25: 257-260.

Harada, H. (1995) Strigula nipponica Harada sp. nov. (Lichenes, Strigulaceae) from Chiba-ken, central Japan. Nova Hedwigia 60: 487-491.

Harris, R. C. (1995) More Florida Lichens, including the 10c tour of the pyrenolichens. New York: privately published.

Lücking, R. (1991) Neue Arten foliikoler Flechten aus Costa Rica, Zentralamerika. Nova Hedwigia 52: 267-304.

McCarthy, P. M. (1995) New saxicolous species of Strigula Fr. (lichenised Ascomycotina: Strigulaceae) from Australia and New Zealand. Muelleria 8: 323-329.

McCarthy, P. M. \& Malcolm, W. M. (1996) Strigula occulta, a new saxicolous lichen from New Zealand. Mycotaxon 60: 323-326.

McCarthy, P. M., Streimann, H. \& Elix, J. A. (1996) New foliicolous species of Strigula from Lord Howe Island, Australia. Lichenologist 28: 239-244.

Roux, C. \& Bricaud, O. (1993) Studo de la genro Strigula (Lichenes, Strigulaceae) en S-Francio. Bulletin de la Société linnéenne de Provence 44: 117-134.

Santesson, R. (1952) Foliicolous lichens I. A revision of the obligately foliicolous, lichenized fungi. Symbolae Botanicae Upsalienses 12 (1): 1-590.

Sérusiaux, E. (1996) Foliicolous lichens from Madeira, with the description of a new genus and two new species and a world-wide key of foliicolous Fellhanera. Lichenologist 28: 197-227.

Sérusiaux, E. \& Polly, B. (1996) Strigula kaitokensis sp. nov. from New Zealand. Mycotaxon 59: 245-251. 